\title{
KEKERASAN GENDER DAN NILAI PENDIDIKAN KARAKTER DALAM CERPEN DUA DAPUR KARYA JM. DIANA DARMANSYAH
}

\author{
Aprizal Maulani $^{1}$, Rusdiawan ${ }^{2}$, Ida Bagus Kade Gunayasa ${ }^{3}$ \\ Magister Pendidikan Bahasa Indonesia, Universitas Mataram \\ Email:aprizalmaulani91@gmail.com
}

\begin{abstract}
Abstrak
Penelitian ini bertujuan untuk mendeskripsikan wujud kekerasan emosional maupun fisik pada perempuan dalam cerpen Dua Dapur. Jenis penelitian ini menggunakan metode kualitatif deskriptif, dengan objek penelitian adalah wujud kekerasan gender pada perempuan dalam cerpen Dua Dapur menggunakan analisis feminisme. Sumber data penelitian adalah cerpen yang berjudul Dua Dapur Karya Jm. Diana Darmansyah..Data penelitian berupa katakata dalam rangkaian kalimat dan sumber data primer adalah cerpen karya Jm. Darmansyah. Teknik pengumpulan data menggunakan metode pustaka, simak, dan catat. Teknik analisis data menggunakan teknik analisis isi. Yaitu menganalisis isi dari cerpen Dua Dapur dan dikorelasikan dengan nilai-nilai pendidikan karakter. Dari analisis cerpen Dua Dapur wujud kekerasan yang ditemukan pada perempuan, yakni kekerasan emosional dan kekerasan fisik. Berdasarkan pengamatan yang sudah dilakukan dalam penelitian ini dapat disimpulkan juga bahwa dalam Cerpen Dua Dapur terdapat nilai-nilai pendidikan karakter diantaranya nilai karakter religius, jujur, kerja keras, cinta damai, dan tanggung jawab.
\end{abstract}

Kata Kunci: Kekerasan, Gender, Cerpen, Feminisme dan Pendidikan Karakter.

\section{A. PENDAHULUAN}

Perempuan diajarkan untuk menghargai dan menghormati laki-laki. Setelah menikah, perempuan diajarkan untuk patuh dan tunduk terhadap suaminya. Perempuan juga diajarkan untuk menjadi orang yang pasrah dan menerima setiap perkataan dan perlakuan dari lelaki yang menjadi suaminya. Perempuan diajarkan untuk menjadi orang yang pasif dan lelaki diajarkan untuk menjadi orang yang aktif.

Realitas yang terjadi di dalam masyarakat juga seringkali tergambar pula melalui karya sastra seperti di dalam cerpen. Di dalam karya sastra, perempuan 
seringkali digambarkan sebagai perempuan yang pasrah dan menerima setiap perlakuan dari lelaki termasuk tindakan kekerasan yang dialaminya. Namun, tidak jarang pula penggambaran tokoh perempuan yang berusaha keluar dari keterkungkungan yang dialaminya. Penggambaran tokoh perempuan yang berusaha keluar dari berbagai tindak kekerasan yang dialami berdasarkan gender merupakan penggambaran perjuangan kaum feminis.

Salah satu cerita pendek yang menggambarkan tentang tokoh perempuan yang berjuang untuk keluar dari segala bentuk kekerasan gender yang dialaminya adalah cerita pendek yang berjudul Dua Dapur karya Jm. Diana Darmansyah. Cerpen tersebut merupakan cerpen yang pernah diterbitkan oleh harian Fajar pada hari Minggu, 31 Juli 2011. Cerpen tersebut juga menjadi salah satu cerpen yang masuk dalam Antologi Cerpen yang bejudul Uang Banyak karya Jm. Diana Darmansyah terbit tahun 2013 oleh penerbit Identitas Universitas Hasanuddin, Makassar. Cerpen yang akan digunakan sebagai objek penelitian adalah cerpen berjudul Dua Dapur yang diterbitkan dalam antologi cerpen Uang Banyak.

Cerpen Dua Dapur mengisahkan tentang seorang tokoh perempuan yang menyaksikan ibunya mengalami tindak kekerasan yang dilakukan oleh ayahnya. Ibunya meninggal setelah mengalami tindakan kekerasan yang dilakukan oleh ayahnya. Tokoh perempuan, yaitu tokoh Aku belajar dari pengalaman yang pernah dialami oleh ibunya. Ketika tokoh Aku mengalami tindak kekerasan gender maka tokoh $\mathrm{Aku}$ memutuskan untuk mengambil tindakan sendiri (Darmansyah, 2013:50-57).

Melalui tulisan ini, penulis akan menjawab pertanyaan, bagaimanakah bentuk kekerasan gender dan nilai pendidikan karakter yang dialami oleh tokoh perempuan di dalam cerpen Dua Dapur karya Jm. Diana Darmansyah? Selanjutnya, apakah upaya yang dilakukan oleh tokoh perempuan untuk keluar dari kekerasan gender yang dialaminya? Untuk menjawab kedua pertanyaan tersebut, maka penulis akan menggunakan teori sastra feminis sebagai alat analisis. 


\section{B. KAJIAN TEORI}

Feminisme adalah teori tentang persamaan antara laki-laki dan perempuan di bidang politik, ekonomi, dan sosial; atau kegiatan terorganisasi yang memperjuangkan hak-hak serta kepentingan perempuan (Goefe dalam Sugihastuti, 2000:37). Feminisme selain merupakan gerakan kebudayaan, sosial, politik dan ekonomi, juga merupakan salah satu teori sastra. Teori sastra feminis melihat bagaimana nilai-nilai budaya yang dianut suatu masyarakat. Suatu kebudayaan yang menempatkan perempuan pada kedudukan tertentu serta melihat bagaimana nilai-nilai tersebut memengaruhi hubungan antara perempuan dan lakilaki dalam tingkatan psikologis dan budaya. Studi feminis bertujuan untuk menimbulkan kesadaran yang akan membebaskan manusia (khususnya perempuan) dari masyarakat yang irasional (Maisaroh, 2012:5).

Membahas tentang perempuan dari segi feminis maka tidak bisa terlepas dari masalah gender karena masalah feminis berkaitan dengan konsep seks dan gender. Fakih (2013:7-9) menjelaskan bahwa seks berbeda dengan gender. Seks (jenis kelamin) merupakan penyifatan atau pembagian dua jenis kelamin manusia yang ditentukan secara biologis yang melekat pada jenis kelamin tertentu. Seks atau jenis kelamin secara permanen tidak bisa berubah dan merupakan ketentuan biologis atau disebut sebagai kodrat. Adapun konsep gender, yakni suatu sifat yang melekat pada kaum laki-laki maupun perempuan yang dikonstruksi secara sosial maupun kultural. Konsep gender menyangkut semua hal yang dapat dipertukarkan antara sifat perempuan dan laki-laki, yang bisa berubah dari waktu ke waktu, dari suatu tempat ke tempat lainnya dan dari suatu kelas ke kelas lainnya.

Ketidakadilan yang disebabkan oleh adanya perbedaan gender merupakan salah satu masalah yang mendorong lahirnya feminisme. Menurut Fakih (2013:12-13) ketidakadilan gender termanifestasi dalam berbagai bentuk ketidakadilan, yaitu marginalisasi atau proses pemiskinan ekonomi, subordinasi atau anggapan tidak penting dalam keputusan politik, stereotipe atau melalui pelabelan negatif, kekerasan, beban kerja serta sosialisasi ideologi nilai peran gender. 
Penggambaran ketidakadilan gender biasanya terdapat di dalam karya sastra, sehingga karya sastra perlu diteliti berdasarkan pandangan feminisme. Tong (dalam Amal, 1995:85-107) mengemukakan mengenai beberapa perspektif yang digunakan dalam menjawab permasalahan wanita, yaitu feminisme Liberal, feminisme Marxis, feminisme Radikal, feminisme Psikoanalisis, feminisme Sosialis dan feminisme Eksistensialis.

Feminisme liberal beranggapan bahwa semua orang diciptakan dengan hak-hak yang sama, dan setiap orang harus mempunyai kesempatan yang sama untuk memajukan dirinya. Gerakan ini beranggapan bahwa sistem patriarkal dapat dihancurkan dengan cara mengubah sifat masing-masing individu (Sugihastuti dan Sastriyani, 2007:65-66). Asumsi dasar feminisme liberal berakar pada pandangan bahwa kebebasan dan kesamaan berakar pada rasionalitas dan pemisahan antara dunia privat dan publik. Feminis liberal memperjuangkan kesempatan yang sama dan hak yang sama bagi setiap individu termasuk kesempatan dan hak kaum perempuan. Kesempatan yang sama antara laki-laki dan perempuan karena perempuan adalah makhluk yang rasional juga (Fakih, 2013:81-82).

Feminisme radikal berasumsi bahwa penyebab penindasan terhadap kaum perempuan oleh laki-laki berakar pada jenis kelamin laki-laki itu sendiri dan ideologi patriarkinya. dengan demikian kaum laki-laki secara biologis dan politis adalah bagian dari permasalahan. Bagi kaum feminis radikal menganggap ideologi patriarki adalah penyebab keterbelakangan kaum perempuan (Fakih, 2013:84-85).

Feminisme Marxis berpendapat bahwa ketertinggalan yang dialami oleh perempuan bukan disebabkan oleh individu secara sengaja, tetapi disebabkan oleh struktur sosial, politik, dan ekonomi yang erat kaitannya dengan sistem kapitalisme (Sugihastuti dan Sastriyani, 2007:66). Feminisme Marxis beranggapan bahwa penindasan perempuan adalah bagian dari penindasan kelas dalam hubungan produksi. Penindasan perempuan merupakan kelanjutan dari sistem eksploitatif yang bersifat struktural. Mereka tidak menganggap patriarki ataupun kaum laki-laki sebagai permasalahan. (Fakih, 2013:86-89). 
Feminisme sosialis menegaskan bahwa penindasan perempuan terjadi di kelas manapun. Aliran ini mengkritik asumsi umum bahwa ada hubungan antara partisipasi perempuan dalam produksi dan status perempuan. Ketidakadilan bukanlah akibat dari perbedaan biologis, tetapi karena penilaian dan anggapan terhadap perbedaan itu. Ketidakadilan bukan pula disebabkan kegiatan produksi atau reproduksi dalam masyarakat melainkan karena manisfestasi ketidakadilan gender yang merupakan konstruksi sosial. Oleh karena itu, yang diperangi adalah konstruksi visi dan ideologi masyarakat serta struktur dan sistem yang tidak adil yang dibangun atas bias gender (Fakih, 2013:90-93).

Karya sastra yang baik akan mengandung nilai-nilai karakter di dalamnya. Nilai-nilai karakter tersebut dapat diteladani oleh para pembaca setelah membaca cerpen tersebut dan menerapkannya dalam kehidupan sehari-hari. Wynne (dalam Mulyasa, 2012:3) mengemukakan bahwa karakter berasal dari bahasa Yunani yang berarti "to mark" (menandai) dan memfokuskan pada bagaimana menerapkan nilai-nilai kebaikan dalam tindakan nyata atau perilaku sehari-hari.Seseorang yang berperilaku tidak jujur, curang, kejam, dan rakus dikatakan sebagai orang yang memiliki karakter jelek, sedangkan yang berperilaku baik,jujur, dan suka menolong dikatakan sebagai orang yang memiliki karakter atau mulia.

\section{METODE PENELITIAN}

Metode yang digunakan dalam penelitian ini adalah metode kualitatif deskriptif. Menurut Moleong (2002: 6) dalam analisis deskriptif, data yang dikumpulkan berupa kata-kata, gambar dan bukan angka-angka. Objek penelitian yang dianalisis adalah wujud kekerasan gender pada perempuan dalam cerpen Dua Dapur karya Jm. Diana Darmansyah. Data penelitian berupa kata, frasa, klausa, dan kalimat yang terdapat dalam cerpen Dua Dapur karya Jm. Diana Darmansyah. Teknik pengumpulan data menggunakan metode pustaka, simak, dan catat. Teknik pustaka yakni mempergunakan sumber-sumber tertulis untuk memperoleh data (Subroto,1992, 24).Teknik analisis data menggunakan teknik analisis isi, yaitu dengan menguraikan dan menganalisis serta memberikan 
pemahaman atas teks-teks yang dideskripsikan. Isi dalam metode analisis ini terdiri atas dua macam, yaitu isi laten dan isi komunikasi. Isi laten adalah isi yang terkandung dalam dokumen dan naskah, sedangkan isi komunikasi adalah pesan yang terkandung sebagai akibat yang terjadi (Ratna, 2007:48)

\section{HASIL DAN PEMBAHASAN}

Berdasarkan pemaparan sebelumnya, masalah yang akan dibahas di sini adalah kekerasan gender yang terjadi pada tokoh perempuan. Tokoh perempuan yang mengalami kekerasan adalah tokoh Ibu dan tokoh Aku. Kedua tokoh tersebut mengambil sikap dan tindakan yang berbeda dalam menghadapi kekerasan gender yang mereka alami. Berikut gambaran tentang kekerasan gender yang dialami oleh kedua tokoh perempuan dalam cerpen Dua Dapur sebagai berikut.

\section{Kekerasan Gender}

Kekerasan adalah serangan atau invasi terhadap fisik maupun integritas mental psikologis seseorang. Kekerasan terhadap sesama manusia dapat berasal dari berbagai sumber, namun kekerasan terhadap salah satu jenis kelamin tertentu dapat disebabkan oleh anggapan gender. Pada dasarnya, kekerasan gender disebabkan oleh ketidaksetaraan kekuatan yang ada dalam masyarakat (Fakih, 2013:17)

"'Suatu saat jika kamu menikah dan memiliki anak tapi tidak bahagia, kamu akan merasakan penyesalan yang luar biasa dan kamu ingin kembali menjadi seperti remaja yang bebas. Kamu tidak akan pernah bisa melepaskan diri dari keterkungkungan rumah tangga karena kamu akan merasa kasihan pada anakanakmu.'

'Jika ibu tidak bahagia, untuk apa ibu mempertahankan rumah tangga ibu?' lanjutku.

'Jangan pernah berkata demikian anakku, perempuan tidak boleh menentang semua yang dikatakan oleh suaminya.'

'Ibu, jangan terlalu bodoh. Suami bukanlah Tuhan yang harus disembah. Suami hanyalah manusia biasa, seorang lelaki yang bisa melakukan kesalahan seperti kita, perempuan"' (Darmansyah, 2013:50-51). 
Melalui kutipan percakapan di atas menunjukkan ketidakberdayaan tokoh ibu untuk melepaskan diri dari keterkungkungan. Kelemahan tokoh Ibu dalam cerpen tersebut menggambarkan bahwa ia harus menjadi perempuan yang pasrah dan menerima semua perlakuan suaminya. Tokoh ibu menganggap bahwa perempuan tidak akan bisa keluar dari keterkungkungan rumah tangga yang dialami, bahkan tokoh ibu menganggap bahwa perempuan tidak boleh menentang semua perkataan suami.

Perkataan tokoh Ibu menunjukkan adanya penanaman pemikiran bahwa perempuan harus menuruti segala perintah suami dan tidak boleh membantah apa yang dikatakan oleh suami. Perempuan harus pasrah dan menerima semua perlakuan suaminya.

Pemikiran tokoh Ibu berbeda dengan pemikiran tokoh Aku. Tokoh Aku berpikir bahwa perempuan harus keluar dari keterkungkungan yang dialaminya. Perempuan harus membebaskan dirinya. Menurutnya, lelaki yang menjadi suami adalah manusia, sama seperti perempuan. Maksudnya adalah lelaki dan perempuan sama-sama makhluk ciptaan Tuhan. Perempuan dan lelaki memiliki kedudukan yang sama karena kedua jenis kelamin tersebut merupakan makhluk yang rasional.

Ibuku meninggal dalam kepiluannya karena dihajar tubuh dan hatinya oleh suaminya sendiri, lelaki yang kupanggil ayah. Tubuh dan hati ibu dihajar hingga babak belur. Lelaki yang kupanggil ayah, telah menghajar tubuh ibu dengan tangan kasarnya dan hati ibu dihajarnya dengan cara menikahi mantan kekasihnya. Telah kusaksikan derita ibuku. Cukup pada ibu. (Darmansyah, 2013:52).

Kutipan tersebut menggambarkan tentang kekerasan yang dialami oleh tokoh ibu yang disaksikan oleh tokoh anak. Kekerasan yang dialaminya adalah kekerasan yang dilakukan oleh tokoh ayah. Ayah melakukan tindak kekerasan terhadap fisik tokoh ibu yaitu dengan cara menghajar atau memukul dengan tangan hingga tubuhnya babak belur. 
Selain tindak kekerasan fisik, tokoh ibu juga mengalami tindak kekerasan emosional. Sugihastuti dan Saptiawan (2007:183) menyatakan bahwa "kekerasan emosional termasuk kategori kekerasan nonseksual. Jenis kekerasan ini melibatkan secara langsung kondisi psikologis perempuan yang menjadi korbannya". Kekerasan emosional yang dialami oleh tokoh ibu yaitu kekerasan yang dilakukan oleh ayah dengan cara menikahi mantan kekasihnya. Hal tersebut tentu membuat istrinya merasa sakit hati. Tindakan poligami yang dilakukan oleh tokoh ayah merupakan tindakan yang ditentang oleh kaum feminis. Poligami yang dilakukan oleh tokoh ayah tentu membuat tokoh ibu merasa dikhianati. Stanton (dalam Madsen, 2000:38-40) mengemukakan bahwa hubungan antara lelaki dan perempuan dalam perkawinan sebagai hubungan kekuasaan, dominasi dan kontrol. Aturan-aturan yang mengikat hubungan suami istrilah yang menyebabkan perempuan mengalami ketidakadilan.

Suamiku malah menamparku. Tamparan ini merupakan tamparannya yang kesekian kali. Sebelumnya, aku masih diam, membiarkannya dan membiarkan diriku dalam rasa sakit. Rasa sakit tetaplah rasa sakit. Rasa sakit terkadang membuat trauma orang-orang yang rasa. Aku tak bisa membiarkan diriku dalam rasa sakit ini. (2013:53)

Tindak kekerasan fisik juga dialami oleh tokoh aku. Ia seringkali ditampar oleh suaminya. Awalnya tokoh aku hanya diam dan membiarkan dirinya dalam rasa sakit, namun semakin sering ia mengalami tindak kekerasan tersebut membuatnya semakin berani memberontak. Ia berpikir bahwa segala bentuk tindak kekerasan yang dialami oleh siapapun tentu akan membuatnya merasa trauma. Ia berpikir bahwa ia harus mengambil tindakan untuk keluar dari rasa sakit yang dialaminya.

“'Kamu ini semakin berani sama saya! Ingat! Kamu itu perempuan, kamu itu istriku, jadi jangan pernah membantahku!' Bentaknya.

'Kamu juga perlu ingat, kamu bukan Tuhan, jadi tak ada yang perlu aku takuti.'

'Sejak kapan kamu seberani ini pada saya, suamimu ini?'

'Sejak aku terlalu sering merasakan sakit di hati dan tubuhku! Itu bukan sekali aku rasakan. Sering!’” (Darmansyah, 2013:54). 
Kutipan tersebut menggambarkan bahwa tokoh aku mulai berani mengambil tindakan. Perlawanan yang dilakukannya terhadap tokoh suami membuat tokoh suami marah. Suami beranggapan bahwa istri tidak boleh melawan suami. Tokoh suami menginginkan tokoh aku (istri) sebagai perempuan yang penurut termasuk menuruti dan menerima semua tindakan kekerasan yang dilakukannya. Segala tindakan suami seolah-olah semuanya benar. Bahkan tindakan kekerasan yang dilakukannya terhadap istri dianggapnya benar dan pantas dilakukan. Hal tersebut menunjukan bahwa lelaki dengan ideologi patriarkinya menganggap segala bentuk tindakannya termasuk tindak kekerasan yang dilakukannya karena kesalahan istri.

Bhasin dan Khan (1999:25) menjelaskan bahwa patriarkhi berarti kekuasaan sang ayah. Hal itu berkaitan dengan sistem sosial, di mana sang ayah menguasai semua anggota keluarganya, semua harta milik serta sumber-sumber ekonomi, dan membuat semua keputusan penting. Sistem sosial tersebut menimbulkan ideologi bahwa lelaki lebih tinggi kedudukannya dibanding perempuan; bahwa perempuan harus dikuasai oleh lelaki, dan merupakan bagian dari harta milik lelaki. Diana (2011:15) mengemukakan bahwa adanya ideologi patriarkhi yang menyebabkan perempuan dikontrol dan dikuasai sepenuhnya oleh laki-laki. Dengan demikian feminisme muncul sebagai upaya perlawanan terhadap kontrol laki-laki atas diri perempuan dan bukan sebagai upaya perempuan untuk mengontrol atau menguasai lelaki.

"Belakangan aku tahu uang yang pernah dia katakan hilang itu justru masih terselip di saku celananya. Putriku menceritakannya padaku. Sembilan tahun dia berusaha menghindariku hanya karena kesalahannya sendiri. Kesalahannya karena telah salah menyelipkan uangnya. Ia menganggapku salah karena telah melawan perkataannya dan telah berani membalas tamparannya. Itu kesalahanku, menurutnya. Tidakkah ia salah telah menamparku? Benarkah lelaki itu dibenarkan jika menampar seorang perempuan? Di mana letak kebenarannya?" (Darmansyah, 2013:55).

"Sebagai seorang lelaki dia selalu merasa benar. Bahkan dengan menamparku. Ia menganggapnya sebagai kesalahanku 
karena selalu membantah apa yang dia katakan. Jika aku tidak melakukan kesalahan, untuk apa aku mengakui kesalahan yang justru dilakukannya sendiri. Terlalu egois dia" (Darmansyah, 2013:56).

Kutipan di atas menggambarkan bahwa tokoh aku telah mengetahui bahwa suaminya sendiri yang telah salah menyelipkan uangnya. Kesalahannya menyelipkan uang yang membuat tokoh suami menuduh istrinya mengambil uang tersebut. Bahkan suami berkali-kali menampar istrinya. Ketika istrinya melawan, tokoh suami justru semakin marah bahkan hingga sembilan tahun ia tidak menegur istrinya.

Kutipan tersebut juga menunjukkan adanya protes tokoh perempuan terhadap tindak kekerasan yang dialaminya. Ia memprotes bahwa tindakan kekerasan yang dilakukan oleh lelaki dengan ideologi patriarkinya itu adalah kesalahan dan tidak bisa dibenarkan sama sekali. Lelaki tidak dibenarkan menyalahkan perempuan atas kesalahan yang dilakukannya sendiri. Tokoh aku tentu tidak ingin mengakui kesalahan yang tidak dilakukannya bahkan dia berusaha membantah dan melawan.

\section{Upaya Keluar dari Kekerasan Gender}

Cerpen Dua Dapur menggambarkan tentang tokoh aku yang mulai berpikir tentang upayanya untuk keluar dari kekerasan gender yang dialaminya. Ia merasa tidak nyaman dengan perlakuan suaminya yang selama sembilan tahun hidup serumah tapi tidak menegurnya. Selama sembilan tahun mereka hidup dalam satu rumah tapi memiliki dua dapur. Mereka memiliki dapurnya masingmasing. Tokoh aku menganggap dirinya sebagai perempuan bodoh jika dia tidak berani mengambil langkah atau keputusan sendiri. Ia menganggap dirinya lebih bodoh dari tindakan ibunya. Maksudnya ialah dia tidak ingin mempertahankan rumah tangganya yang sebenarnya sudah tidak bisa dipertahankan. Hal tersebut dapat dilihat dalam kutipan di bawah ini. 
"Suatu waktu aku mulai gerah dengan kelakuannya yang memperlakukanku seolah-olah bukan istrinya. Aku mulai bosan dengan cara hidup dalam satu rumah memiliki dua dapur. Sembilan tahun kami tak saling sentuh-menyentuh. Jika kubiarkan diriku terus seperti ini, maka kuanggap diriku sebagai perempuan terbodoh di dunia ini. Lebih bodoh dari yang pernah dilakukan ibuku. Perempuan yang tak pernah berani mengambil langkah untuk kehidupan sendiri” (Darmansyah, 2013:56).

Tokoh aku benar-benar mengambil keputusan. Ia menggugat cerai suaminya. Hal tersebut dapat diketahui melalui kutipan di bawah ini.

"Di tahun kesembilan ini. Hari ini juga aku mendatangi pengadilan agama. Kugugat cerai lelaki yang serumah dengan ku selama ini. Aku putuskan untuk bercerai darinya. Setelah melalui berbagai proses persidangan aku resmi ditalak. Kukukuhkan hatiku agar tak pernah ingin kembali hidup serumah dengan lelaki seegois dia"(Darmansyah, 2013:56-57).

Kutipan tersebut menunjukkan bahwa tokoh aku yang merasa tidak nyaman lagi hidup bersama suaminya mulai mengambil keputusan untuk menggugat cerai suaminya. Ia menguatkan hatinya sendiri untuk tidak kembali pada suaminya karena ia tidak ingin lagi hidup terkungkung. Ia membebaskan dirinya dari kekerasan yang selama ini dialaminya.

"Sekarang aku hidup sebagai perempuan tua yang menikmati masa tua seperti menikmati masa remaja. Penuh keceriaan. Ini luar biasa. Sangat luar biasa. Dua puluh sembilan tahun aku mengabdi pada seorang lelaki yang ku sebut suami dan sekarang kunikmati sisa hidupku dengan memiliki rumah dan hanya satu dapur. Dapurku sendiri. .... Justru aku telah memilih menentukan arah hidupku sendiri tanpa harus merasa tidak tega pada anak-anakku. Ku kebalkan hatiku, seperti pesan terakhir ibu" (Darmansyah, 2013:57).

Kutipan di atas menggambarkan tentang kehidupan tokoh aku yang telah merasa bebas. Ia menikmati hidup sendiri di rumahnya dengan dapurnya sendiri. Setelah dua puluh sembilan tahun ia berusaha mempertahankan rumah tangganya. 
Namun rumah tangga yang coba ia pertahankan justru membuatnya merasa tidak nyaman.

Pernikahan yang dijalani oleh tokoh Aku merupakan sebuah pernikahan yang tidak bahagia. Itulah yang menyebabkan tokoh Aku berusaha keluar dari ketidakbahagiaannya. Inilah sesungguhnya yang dikhawatirkan oleh kaum feminis. Sebenarnya kaum feminis tidak menentang perkawinan seperti yang dikemukakan oleh Stanton (dalam Muslimat, 2005: 29) bahwa feminis liberal tidak menolak perkawinan bahkan menganggap perkawinan sebagai sesuatu yang wajar dan normal tetapi aturan-aturan yang mengikat hubungan suami istrilah yang membuat perempuan tertekan dan tersubordinasi.

Dapat dipahami bahwa pernikahan bukanlah hal yang ditentang oleh kaum feminis, jika orang yang menjalani kehidupan rumah tangga merasa aman dan nyaman dalam menjalaninya. Hal yang ditentang oleh kaum feminis adalah segala bentuk ketidakadilan yang terjadi di dalamnya. Hal tersebut yang membuat kaum feminis memperjuangkan kaum perempuan untuk keluar dan membebaskan diri.

3. Nilai Pendidikan Karakter dalam Cerpen Dua Dapur karya Jm. Diana Darmansyah

Setelah dibaca, dipahami, dan dianalisis berdasarkan kajian teori, nilai pendidikan karakter yang dapat ditemukan dalam cerpen Dua Dapur karya Jm. Diana Darmansyah ini, antara lain.

\section{a. Religius}

Dalam cerita ini, nilai karakter religius ditunjukkan oleh tokoh Aku. Mengamalkan perintah agama yang bernilai ibadah yaitu menikah, walaupun ada sedikit keraguan karena pengalaman dari sang Ibu yang telah ditinggal oleh suaminya.

\section{b. Jujur}

Dalam cerita ini, nilai karakter jujur ditunjukkan oleh tokoh Aku. Saat dituduh oleh suaminya Aku mengakui dan berkata jujur bahwa ia tidak pernah mengambil uang suaminya yang saat itu hilang di dalam dompetnya. 


\section{c. Kerja keras}

Sikap kerja keras dalam cerpen Dua Dapur karya Jm. Diana Darmansyah ditunjukkan oleh tokoh Aku dan Ibu, bekerja keras untuk menghidupi anakanaknya setelah bercerai dengan suaminya

\section{d. Rasa ingin tahu}

Sikap rasa ingin tahu ditunjukkan oleh tokoh Aku. Sebagai seorang perempuan yang ingin bahagia, rasa ingin tahunya sangat tinggi. Ini ditunjukkan saat hendak memaksa sang ibu menceritakan pengalaman rumah tangganya. Tujuannya agar kelak ia bisa belajar dari pengalaman sang ibu dan tidak mengalami kepahitan seperti ibunya.

\section{e. Cinta damai}

Sikap cinta damai dalam cerpen Dua Dapur karya Jm. Diana Darmansyah ditunjukkan oleh tokoh Aku dan Ibu. Ia dan ibunya tidak pernah membalas perlakuan yang dilakukan oleh suaminya walaupun terkadang suaminya melakukan kekerasan fisik namun ia tidak pernah membalasnya.

\section{f. Tanggung jawab}

Nilai tanggung jawab dapat ditemui pada tokoh Aku dan Ibu,sang Ibu bertanggungjawab untuk menghidupi anaka-anaknyaseorang diri ketika diceraikan oleh suaminya. Tokoh Aku dengan keputusannya menikah walaupun sudah tahu pengalaman pahit yang dialami oleh orang tuanya. Tokoh Aku juga bertanggung jawab mencukupi kebutuhan hidup anak-anaknya seorang diri setelah ia diceraikanoleh suaminya. Tokoh Aku dan Ibu tipikal wanita yang bertanggung jawab dan pekerja keras. 


\section{E. SIMPULAN}

Berdasarkan pembahasan di atas dapat disimpulkan bahwa tokoh ibu yang mengalami tindakan kekerasan fisik dan emosional oleh suami tetap berusaha untuk mempertahankan kehidupan rumah tangganya karena ia menganggap bahwa perempuan tidak boleh membantah segala perbuatan suaminya. Penggambaran tokoh ibu yang mengalami tindak kekerasan hingga meninggal dunia berbeda dengan penggambaran tokoh Aku (anak) yang telah berusaha mempertahankan rumah tangganya namun ia merasa tidak nyaman dengan kehidupan rumah tangga yang dijalaninya akibat tindak kekerasan yang dilakukan oleh suaminya. Tokoh Aku berusaha untuk membebaskan diri dari ketidaknyamanan tersebut dengan cara bercerai dari suaminya. Hal tersebut sejalan dengan gagasan kaum feminis bahwa mereka tidak menolak pernikahan, melainkan ketidakadilan-ketidakadilan yang terjadi dalam rumah tangga itulah yang mereka tentang. Mereka menganggap bahwa perempuan harus membebaskan diri dari ketidakadilan tersebut. Hasil penelitian ini juga diharapkan dapat membantu para pembaca untuk mengembangkan nilai-nilai karakter seperti yang terkandung dalam cerpen Dua Dapur karya Jm. Diana Darmansyah. Selain itu, hasil penelitian ini diharapkan mampu menambah minat masyarakat untuk membaca sehingga pembaca memiliki dan memahami termasuk nilai-nilai karakter yang terdapat dalam bacaan,khususnya karya sastra.

\section{Daftar Pustaka}

Amal, Siti Hidayati. 1995. "Beberapa Perspektif Feminis dalam Menganalisis Permasalahan Wanita" dalam Ihromi T.O (ed). Kajian Wanita dalam Pembangunan. Jakarta: Yayasan Obor Indonesia.

Bhasin, Kamla dan Nighat Said Khan. 1999. Persoalan Pokok Mengenai Feminisme dan Relevansinya. Jakarta: Gramedia Pustaka Utama bekerjasama dengan Kalyanamitra.

Chasanah, Ida Nurul. 2006. "Presentasi Kekerasan dan Trauma Seksual: Analisis Isi Teks dalam Karya-Karya Djenar Maesa Ayu". Masyarakat, Kebudayaan dan Politik. Tahun XIX, Nomor 2, April 2006.

Darmansyah, Jm. Diana. 2013. Uang Banyak. Makassar: Identitas Kampus Universitas Hasanuddin. 
Diana, Jumianti. 2011. "Gender dalam Novel Perempuan, Rumah Kenangan Karya M Aan Mansyur: Tinjauan Kritik Sastra Feminis”. Makassar: Jurusan Sastra Indonesia Fakultas Ilmu Budaya Universitas Hasanuddin. . 2018. "Citra Sosial Perempuan dalam Cerpen Kartini Karya Putu Wijaya Tinjauan Kritik Sastra Feminis”. Jurnal Pena Indonesia Volume 4 (1) Maret 2018.

Djajanegara, Soenarjati. 2003. Kritik Sastra Feminis: Sebuah Pengantar. Jakarta: Gramedia Pustaka Utama.

Fakih, Mansour. 2013. Analisis Gender dan Transformasi Sosial. Yogyakarta: Pustaka Pelajar.

Madsen, Deborah L. 2000. Feminist Theory and Literary Praktice. London: Pluto Press.

Maisaroh, Siti. 2012. Matinya Sastra Feminis: Kritik Komposisi Gerak Feminisme dalam Karya Sastra. Malang: Beranda.

Moleong, Lexy, 2002. Metodologi Penelitian Kualitatif. Bandung. PT. Remaja Rosdakarya.

Mulyasa. 2012. Manajemen Pendidikan Karakter. Jakarta: Bumi Aksara.

Muslimat. 2005. "Citra Wanita dalam Cerita Rakyat Makassar: Suatu Tinjauan Kritik Sastra Feminis." Yogyakarta: Pascasarjana Universitas Gadjah Mada

Nyoman Kutha Ratna. 2007. Teori, Metode, dan Teknik Penelitian Sastra.

Yogyakarta: Pustaka Pelajar.

Subroto.1992. Penelitian Kualitatif. Jakarta: Raja Grafindo Persada.

Sugihastuti. 2000. Wanita Di Mata Wanita. Bandung: Nuansa dan Itsna Hadi Saptiawan. 2007. Gender dan Inferioritas Perempuan: Praktik Kritik Sastra Feminis. Yogyakarta: Pustaka Pelajar. dan Siti Hariti Sastriyani. 2007. Glosarium Seks dan Gender. Yogyakarta: CarasvatiBooks. 